\title{
Długi cień antysemityzmu
}

\section{Marek PĄKCIŃski}

ORCID: OOOO-OOOI-9033-5899

(Instytut Badań Literackich PAN, Warszawa)

RecenZja Książki: Matgorzata Domagalska, Zatrute zlarno. Proza antY-

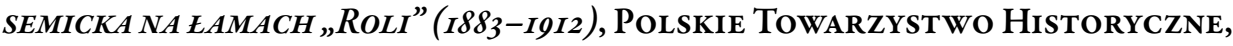
WYDAWNICTWO NERITON, WARSZAWA 2015, SS. 34I

Pisanie na temat polskiego antysemityzmu doby nowoczesności jest zadaniem trudnym i niewdzięcznym. Badawcze „przedzieranie się” przez tego rodzaju teksty wymaga wytrzymałości, motywacji i samozaparcia, jest jednak pracą bardzo potrzebną, ważną zarówno pod względem naukowym, jak i społecznym. Ślad tego wysiłku odnajdujemy w zakończeniu książki Małgorzaty Domagalskiej Zatrute ziarno. Proza antysemicka na tamach „Roli” (I883-I9I2):

\section{\Także dla współczesnego czytelnika lektura trzydziestu roczników pisma stanowi nie lada wyzwanie. Jest jednak niezbędna do ogarnięcia przemian ideologicznych na terenie Królestwa Polskiego, narastania tendencji antysemickich i fobii Jeleńskiego oraz jego sympatyków. Analizując roczniki „Roli”, można prześledzić ewolucję polskiego antysemityzmu i zobaczyć, jak rwący strumyk zamienia się w rzekę zasilaną różnymi dopływami antysemickich uprzedzeń ${ }^{\mathrm{I}}$.}

Do powyższych uzasadnień podjęcia tego wysiłku można dodać jeszcze jedno: pozwala on na zbliżenie się do trafnej diagnozy tego, co zdarzyło się z polską kulturą i świadomością społeczną (a w szczególności z polskim chrześcijaństwem) na przełomie XIX i XX wieku. Zatrute ziarno mówi też wiele o wpływie różnorodnych procesów epoki nowoczesności na społeczeństwa Europy Środkowo-Wschodniej. Autorka, która pracowicie i w przemyślany sposób zebrała materiał źródłowy, nie

1 M. Domagalska, Zatrute ziarno. Proza antysemicka na tamach „Roli” (1883-1912), Warszawa 2015, s. 312-313. 
narzucając przy tym czytelnikowi własnych interpretacji i wystrzegając się nie tylko naukowej publicystyki, lecz również wszelkich przedwczesnych uogólnień, stworzyła syntezę, która daje do myślenia i prowokuje do wyciągnięcia wniosków, mogących przyczynić się do rozwoju naukowej analizy antysemityzmu, wykraczającej poza uzasadnione moralnie oburzenie.

W tym przypadku do odbiorcy (w tym także recenzenta jako czytelnika aktywnego) może należeć niejako próba metarefleksji nad treścią tej książki oraz zgromadzonych w niej - rzetelnie i cierpliwie - wniosków na temat zjawiska antysemityzmu (a w szczególności - antysemityzmu polskiego). Praca zawiera bowiem wiele wątków frapujących i wartych podjęcia, które pozwalają może nie tyle na udzielenie odpowiedzi, ile na sformułowanie pytań w kwestii kondycji polskiej kultury i świadomości społecznej - również w obecnej chwili.

W trakcie lektury nasuwa się między innymi pytanie o paradoksalną nowoczesność antysemityzmu, jego nowatorstwo, dostrzegalne w okresie, gdy wydawana była „Rola” (I88I-I9I2), a polegające na pojawianiu się w tym piśmie motywów i metod ideowej propagandy, zapowiadających bez wątpienia XX-wieczne totalitaryzmy (zwłaszcza niemiecki narodowy socjalizm) i wykorzystujących cały arsenał językowych i pozajęzykowych form oddziaływania, które rozpowszechnią się w zenicie wieku XX. Można też zapytać, jak to się stało, że kilku dość młodych publicystów, pod przywództwem byłego pozytywisty-organicznika Jana Jeleńskiego, z istotnym udziałem najbardziej nowatorskiego z warszawskich „młodych konserwatystów” (oraz założyciela całego tego ugrupowania) Teodora Jeske-Choińskiego, do tego stopnia uznało lęk przed przedstawicielami narodu żydowskiego i wrogość wobec nich za bardzo ważną cechę polskiej mentalności, a szkodliwość mieszkających na polskich ziemiach Żydów - za niepodważalny fakt, że stało się to lejtmotywem ich dalszej działalności. Jak pisał po latach jeden z redaktorów warszawskiej prasy:

\section{\P. Jeleński stawiał pierwsze kroki w „Kurierze Porannym”, gdzie dzięki naszej bezstronności i niezależności umieszczaliśmy jego artykuły około r. 1883. Był to człowiek małej wiedzy, jednostronny, ale odważny w wypowiadaniu swego zdania. Założył on tygodnik „Rolę” w r. 1883 i potrafił zyskać powodzenie, jak każdy, kto gra na jakiej namiętności ludzkiej, a dodajmy, że p. Jeleński grał długi czas zręcznie².}

Ten trafnie dobrany przez autorkę cytat, dotyczący jednego z głównych bohaterów (może raczej: antybohaterów) Zatrutego ziarna naprowadza na trop wątku,

2 Ksiega Jubileuszowa „Kuriera Porannego” 1877-1902, red. F. Fryze, Warszawa 1903, s. 67. Cyt. za: M. Domagalska, Zatrute ziarno..., s. 179. 
który wydaje się powtarzać w tej książce, pośród wielu innych stanowiących klucz do fenomenu publicystyki, grającej na złych ludzkich emocjach: figury dziennikarza - dyletanta. Cała ideowa konstrukcja antysemityzmu wspiera się na tej postaci jako swoistym zworniku konstrukcyjnym budowli społecznego sukcesu. Właśnie dyletantyzm, który najdelikatniej można określić jako brak pieczołowitości i zbyt swobodny stosunek do prawdy, zastępowanej pogłoskami, stereotypami i kliszami, odpowiada za ruchomość, elastyczność antysemickiej retoryki i metaforyki, za ich swobodne przemieszczanie się przez obszary różnych dziedzin nauki - biologię, historię kultury, medycynę, psychologię, socjologię, etykę i tak dalej - aż po nasyconą złymi emocjami i pseudooskarżeniami retorykę „biblijną”.

Temu właśnie językowemu aspektowi „rolarskiej” publicystyki i prozy - rozpatrywanej tu z wykorzystaniem narzędzi retoryki i poetyki - Małgorzata Domagalska poświęca część swoich interpretacyjnych rozważań. Mimo jawnie obsesyjnego charakteru rzucanych pod adresem Żydów oskarżeń i inwektyw, na co zwracała uwagę krytyczna wobec „Roli” prasa zarówno pozytywistyczna, jak i konserwatywna, swoisty, wewnętrzny ruch antysemickiej retoryki polegał najwyraźniej na konkretyzacji metafor lub przeciwnie - na metaforyzacji pozornie jasnych (choć oczywiście w istocie fałszywych) oskarżeń i zarzutów. Ten podskórny ruch konkretyzacji i metaforyzacji odpowiada za przerażającą spójność antysemickiej metaforyki i retoryki, która - jakkolwiek urąga faktom - może wydawać się bardziej logiczna i zwarta od nich (a jest to bez wątpienia jedna z kluczowych cech logiki paranoi). Pod piórem Jeleńskiego, Jeske-Choińskiego, Skrzyneckiego, Gąsiorowskiego, Reinsteina ten nienawistny język wypełnia niejako całe pole semantyczne użytych w dyskursie słów i sformułowań, poruszając się od konkretu do znaczenia przenośnego i z powrotem: w oparciu o średniowieczny przesąd, czyniący z Żydów „sprawców zarazy”, w chwili bieżącej środowiska żydowskie określane są jako „choroba” tocząca organizmy współczesnych społeczeństw; legenda o mordzie rytualnym ożywia z kolei metaforę burżuazyjnych „żydowskich krwiopijców”, żerujących na ciele chrześcijańskiego społeczeństwa, w szczególności proletariatu. Na tej samej zasadzie anonsowany w wielu różnych tekstach i postaciach (a w formie złowieszczo żartobliwej - także w analizowanych w Zatrutym ziarnie powieściach) fizyczny brud Żydów, ich niechęć do wymogów nowoczesnej higieny, wymienia się swobodnie z topiką brudu moralnego, zaś współczesny autorowi przedstawiciel krytykowanej nacji boi się higienicznej kąpieli, jak - w świetle archaicznych wierzeń - „diabeł bał się święconej wody”3.

3 Jak pisze Domagalska: „W opowiadaniu Helistana (Stanisława Maciejowskiego) Wariat („Rola” 1898 , nr 51, s. 862-863) propozycja kąpieli zmusza wędrownego handlarza do ucieczki, co jest metodą bohatera na pozbycie się intruza, traktowaną przez narratora - interlokutora jako nieszkodliwe i zabawne rozwiązanie problemu" (M. Domagalska, Zatrute ziarno..., s. 128). 
Nie trzeba dodawać, jak ponury wydaje się nam z perspektywy czasu ów jowialny humor artykułów „Roli”. W tle tekstów zarówno publicystycznych, jak i beletrystycznych, drukowanych w tym piśmie, odnajdujemy jednak nieustannie postać autora - dyletanta, będącego zarazem domorosłym „antropologiem”, równie dobrze zorientowanym w niuansach obyczajów przedstawicieli innych kultur, co w fizjologii zamieszkujących ich ciała pasożytów. Jak pisze Peter Sloterdijk w eseju O ulepszaniu dobrej nowiny. Piąta „ewangelia” Nietzschego w związku z zainicjowanym przez autora Wiedzy radosnej (po nowoczesnej rewolucji przemysłowej i jej romantycznych projekcjach kulturowych) trendem rozwojowym „fali indywidualizmu”, potrzeba odróżnienia od tłumu stała się pod koniec XIX wieku koniecznym i wystarczającym warunkiem, potrzebnym do osiągnięcia sukcesu na kulturowym „rynku”4. W tym sensie aktem założycielskim kariery takiego self-made mana lub „rynkowego lidera kultury narodowej” jest uświadomienie tłumowi odbiorców jakiejś potrzeby - takiej na przykład jak konieczność uwolnienia się od żydowskich współobywateli lub pragnienie posiadania homogenicznej kultury, wolnej od imigrantów i obcych wpływów - którą następnie obiecuje się zaspokoić. Zaś kluczem do ludzkich serc pozostaje w takim przypadku zawsze obsesyjna (by nie rzec: paranoidalna) konsekwencja poglądów i działań.

Natrafiamy tu na drugi wątek, przewijający się przez książkę Małgorzaty Domagalskiej, którego autorka szczególnie nie uwypukla, choć zdaniem piszącego te słowa jest on w Zatrutym ziarnie nieustannie obecny: związek antysemityzmu z populizmem. Co prawda, czytanie korpusu niechlubnych tekstów, zawartych w rocznikach „Roli”, z tej perspektywy może wydawać się skażone błędem prezentyzmu, a tym samym anachroniczne. Jednakże $z$ drugiej strony można powiedzieć, że to właśnie współczesność nierzadko oświetla przeszłe wydarzenia i formy kulturowe w niepowtarzalny sposób, pozwalając dostrzec ich drugie dno lub takie ich aspekty, które wcześniej ginęły w mroku.

Ów populistyczny wątek pojawia się - co ciekawe - w kontekście deklarowanej przez autorów „Roli” „postępowości” antysemityzmu. Jak pisał jeden z nich, publicysta „Mścisław”, w swoich Listach wiedeńskich:

4 Zob. P. Sloterdijk, O ulepszaniu dobrej nowiny. Piata "ewangelia" Nietzschego. Mowa wygtoszona w Weimarze, 25 sierpnia 2000 r., z okazji setnej rocznicy śmierci Fryderyka Nietzschego, tłum. i red. naukowa T. Słowiński, Wrocław 2010, s. 66.

5 Tak właśnie określa Domagalska Jana Jeleńskiego, powołując się m.in. na diagnozy Ewy Paczoskiej: „Felietonista [Adolf Nowaczyński - M. P.] nie mógł nie podziwiać biografii self-made mana awansującego z posady skromnego telegrafisty na Kolei Warszawsko-Terespolskiej na współpracownika wielu warszawskich pism, a następnie twórcę własnego tygodnika, który redagował przez ponad ćwierć wieku" (M. Domagalska, Zatrute ziarno..., s. 19). 
Program antysemicki jest jasny. Ludność rozumie go bardzo dobrze, dlatego też popiera go z wielkim zapałem; gdzie zaś nie jest on zrozumianym, tam pono świat jeszcze, jak mówią, zabity deskami ${ }^{6}$.

W cytacie tym odnajdziemy kluczowe cechy nowoczesnego (i ponowoczesnego) populizmu: odwołanie się do szerokich rzesz społeczeństwa z pominięciem „elit”, pretendowanie do głębszego i właściwszego rozumienia postępu niż inicjatorzy popularności tego pojęcia (w tym przypadku: pozytywiści). Jak zauważa współczesny politolog, Jan Pakulski:

\begin{abstract}
Nowoczesny populizm pojawił się jako odrębna perspektywa polityczna w czasie wielkich polityczno-ideologicznych konfrontacji na przełomie XIX i XX wieku. Powstał razem ze swym teoretycznym i politycznym nemezis: skupionym na elitach spojrzeniem na polityke („elityzm”) i „teorią elit” dotyczącą zmian politycznych i społecznych. [...] populizm sytuuje się w strumieniu radykalnej myśli utopijnej, która obiecuje egalitarny porządek polityczny („rządy narodu”), kiedy elity zostaną wyeliminowane i przywrócona zostanie właściwa (bezpośrednia, wrażliwa na wolę ludu) demokracja7.
\end{abstract}

To nie konserwatywna krytyka idei postępu i konieczności jej realizacji, lecz poglądy na temat sposobu wcielenia jej w życie oddzielały polonocentrystów-antysemitów od ich pozornie najzajadlejszych przeciwników, pozytywistów. Wydaje się zatem, że nieprzypadkowo spośród „młodych konserwatystów” warszawskich ideologię „Roli” poparł właśnie ten pisarz i publicysta, którego można uznać za najbardziej skłonnego do łączenia konserwatyzmu (ideologii „białego dworku" szlacheckiego) z postępem w wersji Spencera, z uwzględnieniem jego Diltheyowskiej modyfikacji: Teodor Jeske-Choiński ${ }^{8}$. O podatności autorów i publicystów „Roli” na uroki progresywnej utopii - którą będzie można osiągnąć po pozbyciu się mniejszości żydowskiej z ziem polskich - świadczy między innymi obecność na łamach tego pisma utworów z gatunku fantastyki (chodzi na

6 Mścisław, Listy wiedeńskie, „Rola” 1896, nr 47, s. 756 (cyt. za: ibidem, s. 51).

7 J. Pakulski, Populizm i perspektywa elity, w: Almanach 2019/2020 Concilium Civitas, red. J. Żakowski, Warszawa 2019, s. 241-242.

8 Swoistą „otwartość” Jeske-Choińskiego na ideę postępu i gotowość przyjęcia go w pewnej określonej (szanującej walory tradycji) formie wspominała m.in. Zofia Mocarska-Tycowa w książce Dziatalnośc krytycznoliteracka Teodora Jeske-Choińskiego wobec przetomu antypozytywistycznego (Warszawa 1975). 
przykład o powieść Antoniego Skrzyneckiego Warszawa w 2000 roku)9 . Jednakże $\mathrm{w}$ takiej samej mierze, w jakiej hołdował „antysemickiej wersji science fiction”, populistyczny nacjonalizm „Roli” wskrzeszał także ideał utopii regresywnej, polegającej na idealnej jakoby koegzystencji „dworu i chaty” w „rdzennie polskim” pejzażu społecznych relacji (to jest znów po „pokonaniu Innego” lub przed jego zjawieniem się) ${ }^{\text {II }}$. Pod tym względem również antysemityzm „Roli” wpisuje się we wzorcowy model populistycznej ideologii, w której wieś lub prowincja są traktowane jako strefa „quasi-sakralna”, pozytywnie rozumiany matecznik moralnego dobra i harmonii ${ }^{\mathrm{I2}}$.

Wraz z unowocześnieniem charakterystycznego dla „Roli” modelu populizmu pojawia się też inna typowa dla tego zjawiska cecha: postępujące zawężanie pojęcia wspólnoty narodowej, do tego stopnia, że w swoim finalnym kształcie okazuje się ona wspólnotą ideologiczną, grupą ludzi, których jednoczy niepodlegający krytyce światopogląd. $Z$ tym zjawiskiem wiąże się odnotowany przez Małgorzatę Domagalską w publicystyce „Roli” topos „Polaków na usługach Żydów” lub „zżydziałych Polaczków”. Ostatecznie są oni określeni jako zdrajcy, zaś natura ich apostazji - co znamienne - ma przede wszystkim charakter religijny. Jak pisze Kamienny (Jan Jeleński) w swoim stałym felietonie z cyklu Na posterunku:

\section{Wśród społeczeństwa - zamiast chrześcijańskich - krzewią pojęcia najbardziej niemoralne i najbardziej niezdrowe, bo judaistyczne. Siebie}

9 O utopijnym komponencie populizmu i jego uzależnieniu od „polityki emocji” oraz prezentowanej „masom” wizji zwycięskiej „walki z Innym” sugestywnie wypowiada się socjolożka Elżbieta Korolczuk: „Emocje stanowią integralną część populistycznej polityki i strategii [...]. Stanowią też integralną część polityki jako takiej, ale [...] prawicowy populizm opiera się najczęściej na strachu, resentymencie i niechęci do Innego. Tym Innym są najczęściej grupy określane jako elity, których dominacja bywa wyimaginowana. W roli tej występują też grupy mniejszościowe, które $\mathrm{z}$ ofiar stają się zagrożeniem lub sprawcami przemocy. [...] nie wystarczy wzbudzić strach, trzeba też wskazać jego źródło i powiedzieć: pokonamy Ich!" (eadem, Uwiq̨d obywatelstwa socjalnego, w: Almanach..., s. 148).

10 Określenie Małgorzaty Domagalskiej (zob. eadem, Zatrute ziarno..., s. 137).

11 Jak pisze Domagalska o powieści Wincentego hr. Łosia Szloma z Rozdotów (opublikowanej w „Roli” 1888, nr 15): „[...] w tej wersji Żyd - manipulant - winny jest napięciom na linii dworu i chłopskiej chaty. Potrafi wódką podsycić chłopską nienawiść przeciwko szlacheckim ciemiężycielom. Szloma namawia więc Kacpra, aby podpalił dwór, następnie niczym Neron przygląda się pożodze" (ibidem, s. 141).

12 Z tego właśnie powodu (który można określić mianem „spełniania wymogów populistycznej struktury antysemityzmu”) jeden z publicystów „Roli” tak wyraża się o Żydach na wsi: „Wszyscy oni jednakowo przebiegli i «sprytni», wszyscy różnych zawsze niecnych używają sposobów wyzysku i wszyscy szerzą wśród ludu moralną zgniliznę. Czyż więc niesłuszną jest rzeczą, ażeby podobnych krzewicieli złego usunąć naprawdę spośród ludu, usunąć całkowicie ze wsi i to usunąć jak najrychlej” (Gtosy w sprawie żydowskiej, „Rola” 1902, nr 47, s. 741. Cyt. za: ibidem, s. 65). 
zaś samych, pomimo nieraz swojej wiedzy i woli, stawiają w roli powolnych sług Izraela ${ }^{\mathrm{I} 3}$.

Ideologizacja pojęcia narodu (w istocie jeszcze bardziej restrykcyjna niż oparcie go na rasistowskich metaforach „krwi i ziemi”) dowodzi tego, że antysemityzm - wraz ze swoją „twórczością” publicystyczną i literacką - wpisywał się w najbardziej negatywne tendencje nowoczesności. Pozostając reakcją na tę epokę i jednocześnie realizacją jej tendencji, w tej samej mierze aktualizował dziedzictwo długiego trwania średniowiecza, co wykorzystywał jego emocjonalną siłę dla własnego niszczycielskiego rozwoju ku swoistej wersji (ostatecznie ludobójczej) utopii. Jego „rewelatorski” styl przekazu, dzięki któremu mógł prezentować się jako spełnienie ambicji jednostki (a także narodu i jego potencjalnego przywódcy - wodza o proweniencji self-made mana) dotyczących buntu przeciw zewnętrznym uwarunkowaniom, wynikał wyłącznie $z$ bezpośredniego oddziaływania upraszczających rzeczywistość stereotypów na odbiorców prasy i innych środków masowej komunikacji. Rola tych stereotypów i opartego na nich, prostackiego języka - wraz z postępem epoki nowoczesności - bynajmniej nie malała, lecz znacząco rosła ${ }^{\mathrm{I}}$. Należy jednak pamiętać, że przestrzenny i czasowy zasięg ich oddziaływania może trwać jedynie tak długo, jak długo podtrzymuje je energia resentymentu, negatywnej reakcji na zachodzące wokół nas przemiany ${ }^{15}$. Właśnie na uświadomieniu tego ograniczenia cywilizacji resentymentu i powiązanego z nią buntowniczego indywidualizmu dyletantów polega przede wszystkim dydaktyczny walor książki Małgorzaty Domagalskiej.

13 Kamienny [J. Jeleński], Na posterunku, „Rola” 1895, nr 12, s. 182. Cyt. za: M. Domagalska, Zatrute ziarno..., s. 81.

14 Autorka Zatrutego ziarna tak pisze o retoryce programowych manifestów „Roli”: „Sugestia binarnej opozycji i jednoczesna apostrofa [...] implikowała podział na widzących, czy raczej oświeconych, i tych, którzy trwali w kalectwie filosemickim $\mathrm{z}$ wyboru. W funkcji apelatywnej osadzone były ponadto tytuły nawołujące do określonej aktywności. Inwokacyjność i rozkaz nasilały się szczególnie w okresie walki wyborczej do Dumy Państwowej [...]" (M. Domagalska, Zatrute ziarno..., s. 108).

15 Peter Sloterdijk stwierdza w cytowanej już książce: „Jak długo opinia publiczna funkcjonuje jako teatr reżyserski resentymentu, zakłada podatność tekstu na gwałt, a «masowej» publiczności na uwodzenie. [...] Przeszłe i przyszłe faszyzmy nie będą niczym innym niż buntami pełnych energii przegranych, zmieniających reguły, by na czas stanu wyjątkowego odgrywać rolę zwycięzców" (idem, O ulepszaniu dobrej nowiny..., s. 69, 76). 